\title{
The Relationships Between Diversity Management and Employer Branding
}

\author{
Teresa Kupczyk, Aneta Szymańska, Joanna Kubicka \\ University of Business in Wroclaw, Wroclaw, Poland
}

\author{
Anna Oleszkiewicz \\ University of Wrocław, Wrocław, Poland
}

\begin{abstract}
The study contains the results of the survey conducted among 335 representatives of companies. The main aim of the research was to identify the links between diversity management and employer branding. To investigate the existence of relationships between variables, they were subjected to analysis using Spearman's rank correlation coefficient, after prior testing of the assumption of normal distribution of variables. For examining the differences, Mann-Whitney U test was used. It was found that there is a statistically significant positive correlation between the level of diversity management in the organization and the evaluation of the company's image. In particular, this relationship concerns the management of diversity in terms of (order of relationship strength) work style, communication, learning/development, culture, gender, age, family status, political views, nationality, race, and held values. The research carried out also assessed the company's image and established qualities of a good employer. Data analysis was performed from the perspective of criteria such as: gender, age, and position held (management, not management). It turned out that managing diversity constitutes today an important factor in creating the image of the employer.
\end{abstract}

Keywords: diversity management, employer branding, company's image

In the past two decades, the diversity of employees has increased dramatically due to globalization, the internationalization of organizations, demographic determinants, unemployment forcing migrations, legislation allowing for the provision of work in other countries, differences in labor costs and high mobility of young workers. This situation requires the concept of diversity management to be implemented in organizations. Ongoing research and polemics focus mainly on its relationships with:

(1) Human resources management (Shen, Chanda, D’Netto, \& Monga, 2009; Samnani, Boekhorst, \& Harrison, 2012);

(2) Equality and anti-discrimination (Nielsen \& Nelson, 2005; Wrench, 2007; Kupczyk, 2009; Klarsfeld, 2010; Dezso \& Ross, 2012; Richard, Kirby, \& Chadwick, 2013);

Teresa Kupczyk, Ph.D., Prof. WSH, Vice-Rector for Science and Research Affairs, University of Business in Wroclaw; research fields: human resources management, diversity management.

Corresponding author: Aneta Szymańska, Ph.D., MBA, MBA Program Director, University of Business in Wroclaw; research fields: marketing management, brand management.

Joanna Kubicka, Ph.D., University of Business in Wroclaw; research fields: human resources management, diversity management.

Anna Oleszkiewicz, M.A., University of Wrocław; research fields: human resources management, diversity management. 
(3) Effectiveness of teams and organizations (Cox \& Blake, 1991; Roberge \& van Dick, 2010; Pieterse, Knippenberg, \& Dierendonck, 2013; Burke \& Cooper, 2008);

(4) Ethics (Gotsis \& Kortezi, 2013; Paliszkiewicz, 2013; Simola, Barling, \& Turner, 2010; Sison, 2008; Stewart, Volporie, Avery, \& McCay, 2011);

(5) Creativity and innovation (Bassett-Jones, 2005; Roberge \& van Dick, 2010; Roberson \& Park, 2004);

(6) Competitive advantage (Roosevelt \& Thomas, 1991; Roberson \& Park, 2004);

(7) Multiculturalism (Rodriguez-Garcia, 2010; Samnani et al., 2012).

What is lacking is depth studies taking up the issue of diversity management relationships with employer branding. Given the global shortage of talent and competences (Manpower, 2014; World Economic Forum, 2014), it is expected that employers will be forced to take care of the image of a good employer. It will be necessary to attract and retain the best employees, who will better perceive the organization as a good employer, seeing it effectively managing diversity. However, the existence of relationship between diversity management and employer branding has not yet been sufficiently scientifically recognized and discussed. This study can fill this gap. Therefore, the main objective of the research was to identify the existing relations between diversity management and employer branding. The implementation of the research served to verify the hypothesis, consisting in finding that such dependencies exist.

\section{Terminological Findings}

The concept of diversity management in the literature is not unequivocally understood. Diversity management bears a wide range of connotations, but it predominantly refers to voluntary organizational actions designed to generate a process of inclusion of employees from different backgrounds to the formal and informal organizational structures through particular policies, events, and initiatives (Foster-Curtis \& Dreachslin, 2008; Shen et al., 2009; Rodriguez-Garcia, 2010). Diversity management has been described as looking at: (1) the mind set of an organization; (2) the climate of an organization; and (3) the different perspectives people bring to an organization due to race, workplace styles, disabilities, and other differences (Reichenberg, 2001, p. 2).

Diversity management can be defined as "A voluntary and planned program designed to make differences between employees a source of creativity, complementarity and greater effectiveness" (Stockdale \& Crosby, 2004, p. 12). Authors as Syed and Kramar (2009) and Noon (2007) have recently criticized this "business case approach" to managing diversity, arguing that it is detrimental to equality and social justice. The replacement of the social justice rationale by the business rationale has potentially "fatal flaws which can undermine equality outcomes and might ultimately prove to be dangerous for social justice" (Noon, 2007, p. 773).

In empirical research presented in this paper, diversity management has been defined quite broadly, mainly due to the fact that in this dimension, it is perceived by employees of enterprises. It was understood as a strategy of personnel management, based on the belief that the diversity of staff (all its possible aspects, in terms of which people are different from each other and area like) is one of the key resources of an organization, which under certain conditions can become a source of business benefits. It involves taking into account and optimizing diversity in the workplace in terms of, e.g., age, gender, (dis)ability, and multiculturalism. It creates equal opportunities for all, uses flexible working hours, makes it easier to reconcile professional and private life, implements organizational culture realizing diversity management standards, adjusts the employment structure and the method of recruitment, remuneration and employees' development, taking into account diversity. 
Another term under consideration, which needs to be defined, is employer branding. In today's highly competitive job market, employer branding is the vehicle that communicates the company's culture and values to the marketplace and a crucial tool for an organization for attracting, recruiting, and retaining the right kind of talent-ideal workers. It helps to recruit highly-skilled and promising new employees and enhances their loyalty by increasing their identification with the company. It also raises the organization's visibility in the job market and makes it stand out from the competition, as well as helps secure the achievement of the company's business plan. A successful employer branding strategy increases profitability, attracting the best talent by creating the perception of the company as a dynamic and innovative place to work, caring about its employees, and offering opportunities for personal fulfillment and professional advancement. However, surprisingly, recent research has shown that only about half of companies have a comprehensive employer branding strategy defined and implemented (Tolan, 2014).

\section{Literature Review}

The concept of employer brand was first introduced in 1996, where the authors defined "employer brand" as "the package of functional, economic and psychological benefits provided by employment, and identified with the employing company" (Ambler \& Barrow, 1996, pp. 185-206). Davis and Moir (2012) defined employer branding as "a generalised recognition for being known among key stakeholders for providing a high quality employment experience, and a distinctive organizations identity which employees value, engage with and feel confident and happy to promote to others". One of the factors which influence the perception of the company as a good employer is diversity management.

A diverse workforce helps organizations attract the most talented employees, and by doing so, helps them achieve the key performance objectives. A variety of recent studies indicate that having employees who reflect the diversity of the population (in terms of culture, race, gender, etc.) enhances employer branding. Promoting diversity in the workplace goes beyond the dimension of corporate social responsibility. Diversity strengthens employer brand, creating the perception among talented prospective employees that the company which wants to attract them is an innovative, dynamic, and creative organization (Araujo, 2015).

According to a recent study from Deloitte (a GovLab report, 2013), diversity in race and gender generates diversity of thought, which in turn helps guard against groupthink and expert overconfidence, it helps increase the scale of new insights, it helps organizations identify the right employees who can best tackle their most pressing problems. As other research studies (conducted by MIT's Sloan School of Management and Rutgers University $^{1}$ ) have indicated, employees from diverse backgrounds function better in teams than those whose members are homogeneous. Therefore, teamwork and collaboration are critically important to workplace dynamism and employee satisfaction. Yet, another research (carried out by Universum ${ }^{2}$ - a global leader in employer branding) has revealed $80 \%$ of the polled students (including $85 \%$ of women) felt it was important that an employer "engages in creating a diverse and inclusive workplace", indicating wide-ranging diversity constituents, such as gender, nationality, ethnicity, age, socio-economic background, sexual orientation, religion, and physical disability.

The analysis of diversity management content and function suggests its direct reference to employer branding, although the latter notion is much more wide as the concept and includes diversity management

\footnotetext{
${ }_{1}^{1}$ See http://www.hcareers.com/us/resourcecenter/tabid/306/articleid/327/default.aspx (accessed July 4, 2015).

2 See http://universumglobal.com/ (assessed July 4, 2015).
} 
together with other issues. Nevertheless, these two notions have many elements in common: target groups, objectives, and content communicated in the process of shaping the intentional image of the employer. Diversity management shapes both employees' corporate identification inside of the organization (internal diversity management effect), and corporate social responsibility outside of the organization (external diversity management effect). The first one-corporate identity-has direct impact on employees' motivation, engagement in work, and also work efficiency, and therefore creates the brand inside the company, the second one-corporate social responsibility - acts as an important public relations tool shaping the brand outside the company. On the basis of these assumptions, it can be stated that there is an existence of feedback between employer's branding and diversity management seen as the projection of the organizational culture and its corporate values (Matuska \& Sałek-Imińska, 2014). The probable interconnections between all the above mentioned factors have been illustrated in Figure 1.



Figure 1. Links among employer branding, diversity management, and corporate identity. Source: Matuska and Sałek-Imińska (2014, p. 80).

In an increasingly globalized environment, companies must manage widely dissimilar employee populations, markets, cultures, and modes of work. The level of ethnic, cultural, generational, and gender diversity of individuals working within a single organization is increasing (Beechler \& Woodward, 2009, p. 276). Therefore, managing employee differentiation through understanding the role of diversity in unlocking the potential of the workforce is certainly one of the key factors determining the success of employer brand strategy (Minchington, 2011).

\section{Research Methodology}

The main objective of the study was to establish relationships between diversity management and a good employer's image. In particular, the analysis took into consideration diversity management links in terms of gender, age, family status, race, nationality, values, political views, culture, style of work, learning and communication. Within the specific objectives, the authors also assessed the image of employers, determined the characteristics of a good employer and factors affecting the improvement in the perception of the company as a good employer. The empirical exploration was carried out to find answers to the following research questions:

(1) How do employees evaluate the image of their employers? 
(2) What are the most important qualities of a good employer?

(3) Which factors do they affect the improvement in the perception of the company as a good employer?

In the preparation phase of the empirical research, it was hypothesized that there are significant relationships between diversity management and the image of a good employer. In order to verify the hypothesis, quantitative and qualitative research was conducted. In preliminary studies, qualitative research was conducted, using individual in-depth interview (IDI) and in-depth telephone interview (ITI). On this basis, a tool was built for quantitative research in the form of survey. The answers to research questions were formed on the basis of employees' opinions. The study was conducted with the sample selection taking into account criteria such as gender, age, and position held (managerial, non-managerial). Convenience sampling was used, which required the resignation of the statistical condition of representativeness of the research. Such a decision was made not only because of the aims of research, but primarily due to research capabilities.

The research comprised $335(\mathrm{~N})$ representatives of companies from the area of Lower Silesia in Poland, including 180 women and 155 men. The dominant group among the respondents was under the age of 35 years (72\%). Persons aged 36-50 years represented 22\%. The smallest group constituted respondents aged over 50 years $(6 \%)$. Managerial staff accounted for $28 \%$, and persons not performing managerial functions- $72 \%$. For depth data analysis in relation to the results of qualitative IDI/ITI research, qualitative analysis was used, and for quantitative research data, statistical analysis was used, using SPSS programme, version 21 (Field, 2013). To investigate the existence of relationships between variables, they were subjected to analysis using Spearman's rank correlation coefficient, after prior testing of the assumption of normal distribution of variables. For examining differences, Mann-Whitney U test was applied.

\section{Results and Interpretation}

The respondents were asked to evaluate the image of their employer. Using a six-point Likert scale (0-5, 0 - very negative, 5 -very positive), they estimated it at $\mathrm{M}=2.94(\mathrm{SD}=1.5)$. This means that employees have some reservations about their employer and evaluated its image at an average level. Mann-Whitney $U$ test showed a statistically significant difference between women and men in the assessment of the employer's image $(p<0.05)$. Women assessed the image of the employer significantly lower $(\mathrm{M}=2.74, \mathrm{SD}=1.5)$ than men $(\mathrm{M}=$ $3.18, \mathrm{SD}=1.5$ ). No differences were identified in the assessment of corporate image depending on the age of the respondents or their positions (managerial, non-managerial).

The respondents identified the most important characteristics of a good employer. The key ones turned out to be: enabling employees professional development, creating friendly atmosphere, providing stability of employment, having a stable financial situation, offering high-quality training, enabling to strike a balance between work and personal life, offering high salary, job flexibility, and innovation. One of the characteristics of a good employer turned out to be diversity management (17\% of responses). A complete list of features of a good employer according to the respondents is presented in Table 1.

Among the factors having an impact on improving the perception of the company as a good employer the respondents pointed to: good treatment of employees, creating a positive image (PR), transparency and honesty, high position in international economic rankings, proceeding in accordance with the principles of business ethics, innovation, knowledge of customer needs and ability to meet them, active communication with the market environment, and the implementation of corporate social responsibility strategy. A complete list of factors is presented in Table 2 . 
Table 1

The Key Features of a Good Employer in the Respondent's Opinions

\begin{tabular}{ll}
\hline Features of a good employer & Percent of indications (\%) \\
\hline Enabling professional development & 58 \\
Friendly atmosphere in the workplace & 52 \\
Stability of employment & 44 \\
Stable financial situation & 43 \\
High-quality trainings & 38 \\
Enabling to strike a work-life balance & 36 \\
High salary offered & 29 \\
Elasticity of employment & 27 \\
Innovation & 25 \\
High quality products/services & 23 \\
Strong management & 21 \\
Dominant position on the market & 20 \\
Diversity management & 17 \\
Commitment to environment and society & 16 \\
Expressive corporate image & 14 \\
Good location & 13
\end{tabular}

Note. Source: The authors' own research.

Table 2

Factors Influencing the Improvement in Perceiving the Company as a Good Employer in the Respondents' Opinions

\begin{tabular}{ll}
\hline Factors influencing the improvement in perceiving the company as a good employer & Percent of indications (\%) \\
\hline Good treatment of employees & 49 \\
Creating a positive image (PR) & 42 \\
Transparency and honesty & 39 \\
High position in international economic rankings & 38 \\
Proceeding in accordance with business ethics principles & 38 \\
Innovation in sector & 34 \\
Knowledge of customer needs and ability to meet them & 34 \\
Active communication with business environment & 33 \\
Implementation of corporate social responsibility strategy & 33 \\
Conducting open and honest internal communication & 31 \\
Providing best quality products and services & 29 \\
Environment protection activities & 28 \\
Cooperation with many institutions & 27 \\
Effective management of crisis situations & 21 \\
\hline
\end{tabular}

Note. Source: The authors' own research.

It was found that there exist statistically significant relationships between diversity management and image of the company as a good employer. They were defined on the basis of Spearman's rho, after prior testing of the assumption of the normality of variables distribution for sample size $\mathrm{N}=335$. This assumption was not met, what was determined on the basis of a significant result of Kolmogorov-Smirnov test $(p<0.001)$. Therefore, non-parametric tests were used. 
It was found that there exists a moderate, positive correlation between the level of diversity management in the organization and the assessment of corporate image ( $\mathrm{rs}=0.31, p<0.001)$. In particular, this relationship concerns diversity management in terms of (in order of the relation strength): style of work ( $\mathrm{rs}=0.24$, $p<0.001$ ) and communication style ( $\mathrm{rs}=0.24, p<0.001)$, style of learning/development ( $\mathrm{rs}=0.22, p<0.001$ ), culture ( $\mathrm{rs}=0.20, p<0.005)$, gender ( $\mathrm{rs}=0.16, p<0.005)$, age ( $\mathrm{rs}=0.14, p<0.05)$, family status ( $\mathrm{rs}=0.14$, $p<0.01$ ), political views ( $\mathrm{rs}=0.13, p<0.005)$, nationality ( $\mathrm{rs}=0.13, p<0.05)$, race ( $\mathrm{rs}=0.12, p<0.05)$, and held values ( $\mathrm{rs}=0.11, p<0.05)$.

There were no significant correlations between the level of diversity management in the organization and assessment of the image of the company in the field of disability, ethnic origin, means of resolving conflicts, and religion.

\section{Discussions and Conclusions}

The analysis of the collected data made it possible to draw conclusions from empirical studies and formulate fundamental postulates in relation to the examined economic reality, in the field of the management of diversity and the image of a good employer. They are as follows:

(1) The evaluation of the image of the company as a good employer made by workers is fairly low, which means that they have reservations. It would be worth for employers to undertake establishing what should be changed in their companies to improve this assessment. Especially in the current battle for talent and competency gaps, it may be of strategic importance for the survival and development of the organization;

(2) It turned out that the employees assess the company's image as a good employer regardless of age and held position (managerial/non-managerial). There were, however, significant differences in terms of the employees' gender. It turned out that men rate corporate image higher than women. This may mean that women feel discriminated in some areas and employers treat them worse. This condition is shown in international statistics, confirming that women are at a disadvantage on the labor market, earn less for the same work and have limited access to managerial positions (The European Institute for Gender Equality, 2013; Hausmann, Tyson, Bekhouche, \& Zahidi, 2014; European Union, 2015). Hence, the conclusion is that employers should continue activities for the equality of opportunities for genders in their companies;

(3) It also turned out that modern set of characteristics of a good employer has been significantly expanded in comparison to previous periods (Ambler \& Barrow, 1996; Minchington, 2011). This means that current employees have dramatically increased their expectations. It is worth noting that today a feature that frequently characterizes a good employer is enabling development. This may be due to the prevailing situation on the labor market, which is growing at the fastest pace in the sphere of economy based on knowledge and innovation, requiring from employees' continuous development. Features that a good employer should have today, and which were not present in the past, are: allowing employees to balance work and personal life, offering flexible forms of employment, innovation, diversity management, as well as concern for the environment and society;

(4) The research literature has shown that the relations of diversity management with the image of a good employer are still a poorly explored phenomenon. It should therefore be considered necessary to continue theoretical and empirical exploration in this area, which would rationalize the methodology of research, organize ideas and above all allow to monitor the situation; 
(5) There is a relationship between the level of diversity management in the organization and the evaluation of the company's image. It is strongest in the case of managing diversity in terms of style of work, communication, learning/development, culture, gender, age, and family status. This means that a company wanting to be recognized as a good employer should focus on diversity management, particularly in the above-mentioned areas.

\section{References}

Ambler, T., \& Barrow, S. (1996). The employer brand. Journal of Brand Management, 4, 185-206.

Araujo, J. (2015). How diversity can save your company. Retrieved from http://universumglobal.com/articles/2015/01/diversity/

Bassett-Jones, N. (2005). The paradox of diversity management, creativity and innovation. Creativity and Innovation Management, 14(2), 169-175.

Beechler, S., \& Woodward, I. C. (2009). The global "war for talent”. Journal of International Management, 15, $273-285$.

Burke, R. J., \& Cooper, C. L. (Eds.). (2008). Building more effective organization: HR management and performance in practice (pp. 252-277). Cambridge: Cambridge University Press.

Cox, T. H. (2001). Creating the multicultural organization: A strategy for capturing the power of diversity. San Francisco, CA: Jossey-Bass.

Cox, T. H., \& Blake, S. (1991). Managing cultural diversity: Implications for organizational competitiveness. The Executive, 5(3), $45-56$.

Davis, H., \& Moir, S. (2012). Employer branding: Case studies and comments from industry professionals. Retrieved from https://www.amazon.com/Employer-Branding-Hugh-Davies-ebook/dp/B008TRZWNG

Dezso, C. L., \& Ross, D. G. (2012). Does female representation in top management improve firm performance? A panel data investigation. Strategic Management Journal, 33(9), 1072-1089.

Diaz-Uda, A., Medina, C., \& Schill, B. (2013). Diversity's new frontier: A GovLab report (pp. 8-11). Westlake: Deloitte University Press.

DiTomaso, N., Post, C., \& Parks-Yancy, R. (2007). Workforce diversity and inequality: Power, status and numbers. Annual Review of Sociology, 33, 473-501.

European Union. (2015). Gender equality. Report. Special Eurobarometer 428. Retrieved from http://ec.europa.eu/justice/genderequality/files/documents/eurobarometer_report2015_en.pdf

Field, A. (2013). Discovering statistics using IBM SPSS Statistics. London: Sage Publications.

Foster-Curtis, E., \& Dreachslin, J. L. (2008). Integrative literature review: Diversity management interventions and organizational performance: A synthesis of current literature. Human Resource Development Review, 7(1), 107-134.

Gotsis, G., \& Kortezi, Z. (2013). Ethical paradigms as potential foundations of diversity management initiatives in business organizations. Athens Journal of organisational Change Management, 26(6), 948-976.

Harrison, D. A., \& Klein, K. J. (2007). What's the difference? Diversity constructs as separation, variety, or disparity in organizations. Academy of Management Review, 32(4), 1199-1228.

Hausmann, R., Tyson, L. D., Bekhouche, Y., \& Zahidi, S. (2014). The global gender gap index 2014. World Economic Forum, Geneva.

How does workplace diversity impact team performance? (2007). Retrieved from http://www.hcareers.com/us/ resourcecenter/tabid/306/articleid/327/default.aspx

Klarsfeld, A. (Ed.). (2010). International handbook on diversity management at work: Country perspectives on diversity and equal treatment. Northampton: Edward Elgar Publishing.

Kreitz, P. A. (2008). Best practices for managing organizational diversity. The Journal of Academic Librarianship, $34(2), 102$.

Kupczyk, T. (2009). Women in management and their success factors. Wrocław: WyższaSzkołaHandlowa.

Manpower. (2014). Talent shortage survey. Manpower group's ninth annual. Retrieved from https://www.manpower.de/ fileadmin/manpower.de/Download/2014_Talent_Shortage_WP_US2.pdf

Matuska, E., \& Sałek-Imińska, A. (2014). Diversity management as employer branding strategy-Theory and practice. Human Resources Management \& Ergonomics, 8, 78-80.

Minchington, B. (2011). Where to next for employer branding? Retrieved from http://www.hcamag.com/features/where-to-nextfor-employer-branding-118401.aspx 
Nielsen, L. B., \& Nelson, R. L. (Eds.). (2005). Handbook of employment discrimination research: Rights and realities. Dordrecht: Springer.

Noon, M. (2007). The fatal flaws of diversity and the business case for ethnic minorities. Work, Employment \& Society, 21(4), 773-784.

Paliszkiewicz, J. (2013). Zaufanie w zarzadzaniu (Trust in management). Warszawa: PWN.

Pieterse, A. N., Knippenberg, D. V. A. N., \& Dierendonck, D. V. A. N. (2013). Cultural diversity and team performance: The role of team member goal orientation. ACAD MANAGE J, 56(3), 782-804.

Prasad, A. M., \& Pringle, J. K. (Eds.). (2006). Handbook of workplace diversity (pp. 191-216). London: Sage Publications Ltd.

Reichenberg, N. E. (2001). Best practices in diversity management. Proceedings from the United Nations Expert Group Meeting on Managing Diversity in the Civil Service. May 3-4, United Nations Headquarters, New York.

Richard, O. C., Kirby, S. L., \& Chadwick, K. (2013). The impact of racial and gender diversity in management on financial performance: How participative strategy making features can unleash a diversity advantage. The International Journal of Human Resource Management, 24(13), 2571-2582.

Roberge, M. E., \& van Dick, R. (2010). Recognizing the benefits of diversity: When and how does diversity increase group performance? Human Resource Management Review, 20(4), 295-308.

Roberson, Q. M., \& Park, H. J. (2004). Diversity reputation and leadership diversity as sources of competitive advantage in organizations. Academy of Management Proceedings, F1-F6.

Rodriguez-Garcia, D. (2010). Beyond assimilation and multiculturalism: A critical review of the debate on managing diversity. Journal of International Migration and Integration, 11(3), 251-271.

Samnani, A. K., Boekhorst, J. A., \& Harrison, J. A. (2012). Acculturation strategy and individual outcomes: Cultural diversity implications for human resource management. Human Resource Management Review, 22(4), 323-335.

Shen, J., Chanda, A., D’Netto, B., \& Monga, M. (2009). Managing diversity through human resource management: An international perspective and conceptual framework. The International Journal of Human Resource Management, 20(2), 235-251.

Simola, S. K., Barling, J., \& Turner, N. (2010). Transformational leadership and leader moral orientation: Contrasting an ethic of justice and an ethic of care. The Leadership Quarterly, 21(1), 179-188.

Sison, A. J. G. (2008). Corporate governance and ethics: An Aristotelian perspective. Cheltenham: Edward Elgar.

Stewart, R., Volporie, S. D., Avery, D. R., \& McCay, P. (2011). You support diversity, but are you ethical? Examining the interactive effects of diversity and ethical climate perceptions on turnover intentions. Journal of Business Ethics, 100(4), 581-593.

Stockdale, M. S., \& Crosby, F. J. (2004). The psychology and management of workplace diversity. Malden, MA: Blackwell Publishers.

Syed, J., \& Kramar, R. (2009). Socially responsible diversity management. Journal of Management and Organization, 15, 639-651.

The European Institute for Gender Equality. (2013). Gender equality index, report. Retrieved from http://eige.europa.eu/sites/ default/files/documents/Gender-Equality-Index-Report.pdf

Thomas Jr., R. R. (1992). Beyond race and gender. New York: AMACOM.

Tolan, J. (2014). Make them want you: The importance of employer branding. Retrieved from http://www.businessinsider.com/ make-them-want-you-the-importance-of-employer-branding-2014-9

World Economic Forum. (2014). Matching skills and labour market needs: Building social partnerships for better skills and better jobs. Retrieved from http://www3.weforum.org/docs/GAC/2014/WEF_GAC_Employment_MatchingSkillsLabourMarket_ Report_2014.pdf

Wrench, J. (2007). Diversity management and discrimination. Aldershot: Ashgate Publishing Ltd.

Wziątek-Staśko, A. (2012). Diversity management. Effective tool to motivate employees. Warszawa: Difin. 